\title{
Does public debt stifle economic growth and increase income inequality in Belt \& Road countries? The Role of Corruption
}

\author{
Faisal Mehmood ${ }^{1,2}$ \\ Email:fmehmood_kmu@yahoo.com \\ ${ }^{1} \mathrm{PhD}$ Scholar of Administrative Management, School of Public Administration, Huahong University of Science \\ \& Technology, Wuhan, China \\ ${ }^{2}$ Kohat University of Science \& Technology, Kohat, Pakistan \\ Professor Dr. Wang Bing \\ Email: wbyf_hust@126.com
}

School of Public Administration, Huahong University of Science \& Technology, Wuhan, China

Hameed Khan ${ }^{1,2}$ (corresponding author)

Email: hameed.qec@gmail.com

${ }^{1} \mathrm{PhD}$ Scholar at School of Economics, Jilin University, Changchun, China

${ }^{2}$ Kohat University of Science \& Technology, Kohat, Pakistan

\begin{abstract}
This study seeks to investigate the role of corruption in the relationship between public debt and economic growth in Belt \& Road countries during 1996-2017 by applying the generalized method of moment (GMM). Using grouped and ungrouped samples; the results reveal that public debt plays a significant and negative role in economic growth. Corruption also plays a significant and negative role in economic growth. The interaction terms of public debt and corruption play a significant and negative role in economic growth. Moreover; several robustness checks like fixed and random effect models also confirm the results of the GMM approach. The inclusion of more control variables also confirms the baseline estimation. The impact of Belt \& Road initiative on economic growth is significantly positive. Several policy recommendations can be drawn from this study. The reduction of the adverse effect of public debt and improvement in economic growth can be brought by applying measures that curb corruption and enhance economic collaboration with other economies.
\end{abstract}

Keywords: Public debt, BRI, growth

JEL Classification: C33; H63; O43

DOI: $10.7176 / \mathrm{EJBM} / 11-33-15$

Publication date: November $30^{\text {th }} 2019$

\section{Introduction}

Financial crisis2007-2008 affects the fiscal imbalances of many economies of the world. The crisis originated with the bankruptcy of Lehman Brothers. Almost all the globalized world feels its spillover effects. To control its effect, governments have taken some fiscal and monetary measure to control the effects. However, corruption and the shadow economy affect the remedial measures. Most of the Belt \& Road (BRI) countries are developing and facing rampant corruption (Olken\&Pande, 2011). Therefore, the study aims to investigate the role of public debt in economic growth and income inequality in BRI countries by examining the intermediating role of corruption.

Role of government debt in economic growth gave rise to controversy when the findings of the Reinhart \& Rogoff (2010) came into light. The slower economic performance and controversy further fueled the debate when mistakes in their study were highlighted. The debate continues regarding this macroeconomic issue. The governments usually print money, impose taxation, and other essential measures to curb slower economic performance. For politicians and social scientists, Buchanan (1966) ask an important question-e.g., "When and who pays for public expenditure financed by debt issue, instead of by taxation or the printing of money?"

The neoclassical growth theories argue that capital mobility enhances economic performance. In their initial stages of developments, the countries do not have sufficient amount of resources-e.g., investment opportunities, and capital stock (Chowdhury, 2001). The external debt positively contributes the economic growth so far it is used 
for investment. Similarly, the findings of Burnside and Dollar $\underline{(2000)}$ also report that debt can enhance growth performance under some specific conditions. However, economic growth and investment may also be adversely affected by a higher volume of debt. 'Debt overhang' theory states that whenever the volume of debt is high enough, then it leads to the depressing of investment by anticipating the increased cost of debt servicing (Krugman, 1988; Karagol, 2002). This is called the crowding-out effect of government debt because a limited amount of money left for investment, and it leads to adverse economic growth.

Similarly, the shadow economy and corruption affect the level of public debt. ${ }^{1} \mathrm{~A}$ vast literature shows that corruption is detrimental for economic growth (Mauro, 1995; Mo, 2001; Tanzi\&Davoodi, 2002), reduce foreign direct investment (Wei, 2000; Abed \&Davoodi, 2000); limit productivity (Lambsdorff, 2003). Corrupt countries tend to have larger shadow economy (Friedman, Johnson, Kaufmann, \&Zoido-Lobaton, 2000; Johnson, Kaufmann, \& Shleifer, 1997; Schneider, Buehn, \& Montenegro, 2010), face higher inflation (Al-Marhubi,2000), lower expenditure on health and education (Mauro, 1998) affect state bond ratings (Depken\&Lafountain, 2006), and adversely affect the poor (Justesen\&Bjornskov, 2014). Corruption can also has undermine the firms' performances.Corruption destroys the firms andforeign bank affiliates' financial performance (Van Vu, Tran, Van Nguyen, and Lim 2016; Petrou, 2014). Economic growth and innovation has been discouraged in countries with rampant corruption (Lau, Yang, Zhang, and Leung; 2015).

The previous studies did not convey the clear picture of government debt \& economic growth relationship. Poirson et al., (2004); and Poirson et al., (2002); Cohen (1993) did not find significant evidence to support the view that government debt can crowd out the investment. On the other hand, the findings of several studies report that debt can adversely affect investment and economic growth (Nguyen et al., 2003; Chowdhury, 2001; Elbadawi, 1999). Therefore, our contribution is to provide further insights into the debt and growth literature by exploring the impact of public debt on economic growth in a newly established economic block, i.e., Belt \& Road Initiative (BRI). Moreover, we also provide new insight by seeing the intermediating role of corruption on economic growth. Furthermore, various robustness checks are applied to look more closely the specific relationship, i.e., period specifications, grouped \& ungrouped data analysis, and static as well as dynamic panel estimation (GMM), and inclusion of more robust variables in our analysis.

Similarly, previous studies provide non-conclusive findings of public debt and income inequality Claessens and Perrotti, 2007; De Haan and Sturm, 2017). Previous studies are based on cross-countries with IV and OLS approaches. The techniques estimate the parameters of interest at the mean evaluation by a conditional distribution of the dependent variable. We contribute the literature by examining the effect of public debt on income inequality using the Koenker and Bassett (1978) quantile regression (QR) technique. The QR methodology enables us to examine the effect at different intervals. Similarly, we contribute the existing literature by examining the influence of public debt on income inequality through a transmission channel of corruption.

The paper is organized as follows. The background of the study is described in Section II. The third section deals with the data and estimation methodology. Section IV reports the empirical results. Concluding remarks are given in Section V.

\section{Background}

The debt-growth relationship is interesting for many researcher and policymakers. Since we formulate empirical framework used in our study; therefore, we highlight some of the prominent contributions by the researchers. From a theoretical perspective, there is vast literature showing how economic growth gets influence by public debt. Diamond ( $\underline{1965})$ examined the influence of public debt on long-run equilibrium in growth model. The author came on conclusion that irrespective of financing external or internal debt, the taxes have the same impact on individuals. Greiner (2012) relates a higher public debt ratio with a lower long-run growth rate. However, Greiner (2013) argues that when wage rigidity is assumed, the conclusion is different. Public debt does not affect long-run economic growth or employment, but only the stability of the economy.

Public debt can affect the economic in several ways. Firstly, governments want to reduce the impact of public debt. Therefore, they issue more currency which creates inflations. Secondly, excess public debt may lead to increase the long-term sovereign yields in a nonlinear manner. High long-term return rate will crowd out private investment and reduce productive government investment due to higher capital costs. The situation will hamper the economic growth. Thirdly, public debt has a negative effect on economic growth because it crowd-out domestic investments by reducing personal incomes and raising the distortionary costs of taxation. Checherita Westphal and Rother (2012) conclude that relationship between public debt and economic growth in non-linear. They added

${ }^{1}$ public power for private gain (Buehn\& Schneider, 2009). 
further that negative effect of government debt on growth stands between $70 \%$ and $80 \%{ }^{1}$ The authors identified several transmitting channels through which public debt affect economic growth. The channels are consisting of Total Factor Productivity (TFP), public investment, and private saving.

Moreover, some authors reach opposite conclusions. Puente-Ajovín and Sanso-Navarro (2015) find that when economic growth is slower, then the economic activity affects government debt through automatic stabilizers and the decrease of tax collection. Similarly, Chen (2014) argues that while debt is neutral for the US economy, the debt channels of the US economy are the stock of capital, national saving rates, and real investment. Finally, Sutherland and Hoeller (2012) highlight the transmission channels through which high levels of debt can hamper macroeconomic stability. One channel is to reduce the possibility of a government to respond efficiently to adverse shocks.

Looking at the literature on the debt-growth relationship and debt thresholds, Reinhart, \& Rogoff (2010) explore the possibility of a persistent relationship between high gross central government debt levels, economic growth, and inflation. They report the existence of a weak link between low levels of debt and growth. However, when the debt ratio is over $90 \%$, the economies' growth rates are on average, one percent lower than otherwise. Based on a panel data of advanced and developing countries over 38 years, Woo, \& Kumar (2010) reach on an important conclusion: an inverse relationship between the initial level of government debt and economic growth rate.

\section{Data and estimation methodology \\ 1- Data}

The basis concern of our study is to explore the relationship between public debt, economic growth, and income inequality with the transmission channel of corruption. We use annual data from 1996-2017 relating to BRI countries. The BRI is a newly established economic block and consist of countries from Asia, Europe, Africa, Oceania, and Latin America (see Appendix for list of countries). More than seventy countries are included in BRI. Due to data limitation, our sample restrict to only sixty countries.

Our main variables of interest are public debt and GDP growth. The corruption indices are sourced from Kaufmann et al. (2013) and Transparency International (TI). We include the two kinds of corruption indices to ensure robustness of results. Kaufmann et al. (2013) corruption index ranges from -2.5 (totally corrupt) to 2.5 (not corrupt). The value of Corruption Perceptions Index (CPI) of TI ranges from 0 (totally corrupt) to 10 (not corrupt). The scales of the two indices are reversed for estimation and maintain consistency between the two indices. We reverse the scale for Kaufmann corruption index with 5 for totally corrupt and 0 for not corrupt country. The TI is rescaled with 0 stands for not corrupt and ten totally corrupt.

Moreover, we include shadow economy as one of the controlled variables in our study. The reason for the inclusion of shadow economy is that corrupt countries are having large shadow economies. The shadow economies affect the level of economic growth and public debt. For shadow economies, we rely on the data of Schneider et al. (2010). Schneider et al. (2010) argue that shadow economies become large due to several elements. The elements consist of increasing taxation and higher regulation with lower institutional quality. They use the Multiple Indicator Multiple Cause (MIMIC) approach to estimate the shadow economy because the shadow economy cannot be measured directly. The data run from 1999-2007; therefore, the missing data is interpolated till 2017.

We include foreign direct investment (FDI) as one of our control variables. A plethora of literature shows FDI and economic growth relationship. Several macro-based articles on both developed and developing countries indicate a positive effect of FDI inflows (Olofsdotter1998; Reisen and Soto 2001). However, other studies report an adverse effect of FDI on economic growth (Mencinger2003; Carkovic\& Levine 2005; Johnson 2006; Türkcan, Duman, and Yetkiner2008; Herzer 2012) or an inconclusive effect (De Mello 1999).

Moreover, infrastructure also plays an essential role in economic performance. We include global infrastructure index in this study as our control variable. The construction of the global infrastructure index is explained in Donaubauer et al. (2015). The index is based on transport, energy, ICT (internet and communication technologies), and financial indicators. The data is available from 1990-2010, the rest of it is interpolated. Furthermore, secondary school enrolment and inflation are used as a proxy for human capital and macroeconomic stability. Details of all variables along with their description statistics are given in Table 1.

\footnotetext{
${ }^{1}$ The authors study twelve Euro area countries from 1970 until 2010.
} 
Table 1. Data source and summary statistics

\begin{tabular}{|c|c|c|c|c|c|c|c|}
\hline Variable & Notation & Obs. & Mean & SD & Min & Max & Comment \\
\hline GDP growth (annual \%) & grow & 1,652 & 4.41 & 5.12 & -37.14 & +54.15 & WDI (2018) \\
\hline Public Debt $\%$ of GDP & GD & 955 & 5.3 & 0.4 & 2.3 & 6.5 & WDI (2018) \\
\hline $\begin{array}{l}\text { Corruption Index Kaufmann et al. (ranges } \\
\text { from approximately } 0 \text { (no corruption) to } 5 \\
\text { (high corruption) }\end{array}$ & $\mathrm{KCI}$ & 1,680 & 2.57 & 1.11 & 0.98 & 5 & Kaufmann et al. (2013) \\
\hline $\begin{array}{l}\text { Corruption Perceptions Index TI. (ranges } \\
\text { from } 0 \text { (not corrupt) to } 10 \text { (totally corrupt) }\end{array}$ & TI & 1,680 & 2.98 & 1.43 & 0.00 & 8.8 & $\begin{array}{l}\text { Transparency International, } \\
2013\end{array}$ \\
\hline Shadow economy $\%$ of GDP & shadow & 1,510 & 3.4 & 0.5 & 0.7 & 4.2 & Schneider et al. (2010) \\
\hline Global infrastructure index & GINFRA & 1,652 & 0.8 & 0.4 & -2.3 & 1.7 & Donaubaueret al. (2015) \\
\hline Total debt service ( $\%$ of GNI) & DS & 1,064 & 1.5 & 0.8 & 2.3 & 3.6 & WDI (2018) \\
\hline $\begin{array}{l}\text { Foreign direct investment, net inflows ( } \% \\
\text { of GDP) }\end{array}$ & FDI & 1,680 & 3.7 & 0.2 & 2.3 & 4.5 & WDI (2018) \\
\hline Inflation & INF & 1,680 & 7.8 & 0.3 & 2.3 & 9.8 & WDI (2018) \\
\hline GINI index & GINI & 1,056 & 3.56 & 0.21 & 2.79 & 4.17 & WDI(2018) \\
\hline GDP per capita (constant 2010 US\$) & GDPPC & 1,652 & 8.51 & 1.30 & 5.1 & 11.19 & WDI (2018) \\
\hline Secondary school enrolment (gross \%) & $\mathrm{HC}$ & 1,653 & 4.89 & 0.28 & -2.30 & 5.37 & WDI (2018) \\
\hline Gross capital formation ( $\%$ of GDP) & GCF & 1,652 & 4.92 & 0.21 & -2.30 & 5.44 & WDI (2018) \\
\hline $\begin{array}{l}\text { General government final consumption } \\
\text { expenditure ( } \% \text { of GDP) }\end{array}$ & GE & 1,652 & 3.35 & 0.28 & -2.30 & 4.49 & WDI (2018) \\
\hline Urban population (\% of total) & URBAN & 1655 & 1.64 & 0.20 & 1.07 & 1.95 & WDI (2018) \\
\hline Exports plus imports divided by GDP & OPEN & 1,644 & 1.77 & 0.51 & -0.77 & 2.33 & WDI (2018 \\
\hline School enrollment, secondary (\% gross) & $\mathrm{HC}$ & 1,653 & 4.9 & 0.3 & 2.3 & 5.4 & WDI (2018) \\
\hline
\end{tabular}

Note: All variables have been converted into a logarithmic form for the empirical estimation except the corruption indices.

Before proceeding further, we need to identify the order of integration of variables in order to avoid a possible problem of spurious regression. Table 3(see Appendix) reports the results of the unit root. For robustness check, we report four different kinds of tests' results. All the results show that our variables are stationary at level.

\section{2- Model specification}

We analyze the debt-growth relationship in the neoclassical growth framework. There is always an issue of heterogeneity in cross-country panel analysis; therefore, convergence issue arises. Economies with higher values of real income tend to grow faster than the economies with a higher starting value of real per capita income (Barro and Sala-i-Martin, 2004). However, we use government debt-to-GDP ratio. Rather than the initial per capita income, other aspects also can explain the convergence phenomena.

Our study is designed to estimate the linearities and nonlinearities in the debt-growth relationship in the context of BRI countries. In this paper, we examine the impact of various indicators of debt burden on the economic growth of BRI countries and corruption indices as the transmission channels. Our models take the following forms;

$$
\begin{aligned}
\operatorname{grow}_{i t} & =\alpha_{i t}+\sum_{j=1}^{k} \gamma X_{i t j}+\sum_{m=1}^{p} \delta D E B T_{i t m}+\eta_{t}+v_{i}+\varepsilon_{i t} \ldots \ldots \ldots \text { Equation (1) } \\
\text { GINI }_{i t} & =\alpha_{i t}+\sum_{j=1}^{k} \gamma X_{i t j}+\sum_{m=1}^{p} \delta D E B T_{i t m}+\eta_{t}+v_{i}+\varepsilon_{i t} \ldots \ldots \ldots \text { Equation (2) }
\end{aligned}
$$

Where grow is the GDP growth, $\mathrm{X}_{i t j}$ is a set of control variables, DEBT is public debt, and DS is debt servicing. Subscripts $i$ and $t$ represent panel and time dimension, while $\eta$ and $v$ denote time-specific and country-specific effects. 


\section{3- Estimation methodology}

All explanatory variables used in our empirical model are not strictly exogenous. If this is the case, straightaway panel estimation will yield biased results. Therefore, a test for endogeneity should be applied. If the null hypothesis of exogeneity is rejected, then Arellano- Bover (1995)-Blundell Bond (1998) system GMM estimator will be employed. GMM allows for controlling the joint endogeneity of explanatory variables through the use of internal instruments (see Enders, 2004 and Baltagi, 2005). The tricky issue in GMM methodology is to select valid instruments/moments. No rule of thumb exists in instruments' selection. For this purpose, Murray (2006) discussed various tricks. Two diagnostic tests are there for the validity of instruments. Firstly, we have Hansen test for overidentifying restrictions with the null hypothesis that the instruments are not correlated with the residuals. Secondly, we have Arellano-Bond test for second-order correlation in the first differenced residuals. The advantage of using GMM over the other instrumental variable (IV) methods is that a G MM estimator is more efficient if heteroskedasticity is present. Similarly, a GMM estimator is not worse than an IV estimator if heteroskedasticity is not present. In this study, the lagged values of independent variables have been used as instruments. We also perform a robustness check by the inclusion of additional control variables in our model.

We apply the mentioned estimation technique in this study on aggregated and disaggregated data (by decomposing global sample into various groups like Asia, Europe, and Africa) for various periods (1996-2017, 2013-2017, and 2008-2012). The intention for this disaggregation is to watch the role of corruption in growth and public debt relationship for BRI countries closely. Similarly, the purpose of dividing period is to see the impact of BRI initiative on the relationship.

To see the impact of $B R I$ on growth, we use fixed and random effect models by including period dummy on the aggregate data (global sample). For this purpose, we will divide data into two parts, i.e., 2008-2012 and 2013 2017, by assigning 0 to the former and 1 for the later. Comparative to the random and fixed effect models that are not restricted, the pooled model is restricted and assumes that countries are homogeneous. When it is necessary to control for omitted variables that are constant over time but differ between countries, the fixed-effects model is desirable. Since the fixed effect considers heterogeneity and individual country effects, therefore, it gives better estimates than the pooled model.

On the other hand, no individual country effects are assumed in the random effect model. Hausman (1978) test is employed to choose between fixed- and random-effect models. Hausman test specifies whether the explanatory variables are correlated with specific effects or not. Hausman test makes sure the selection of the model with consistent results. Random effects are not correlated with the explanatory variables is the central assumption in random effect estimation. The fixed effect model is feasible if the p-value is significant, i.e., $<5 \%$. On the other hand, if it is greater than $5 \%$, then the most appropriate model is the random-effects model.

Furthermore, we employ quantile regression $(\mathrm{QR})$ to examine influence of public debt on income distribution in BRI countries. For comparison purpose, we also employ the fixed effect model. QR estimation methodology enables the estimation at different intervals of condition distribution.

\section{Empirical results}

The preliminary estimation is carried out using OLS, panel fixed effects, and the system General Method of Moments (GMM). Given the uncertainty and likely measurement errors in corruption, the estimation is carried out using both the Transparency International (TI) and Kaufmann et al. (2013) corruption indices.

1. Baseline estimation results for different groups of countries during 1996-2017

Table 2 reports the result of system GMM. The results in column (1)-(4) under the global sample heading show that the coefficients of debt and debt-square are significantly negative. The results are consistent with previous studies' findings, i.e., Akram, 2016; and Chen, Yao, Hu, \& Lin, 2017. The coefficients of Kaufmann et al. (2013) corruption index as well TI index are both significant in all columns except the corruption-K that turn out to be insignificant in (2). Similarly, the interaction terms between debt and the corruption indices from column (1)-(4) are significant with correct signs. The results are consistent with findings of the previous studies, i.e.Cieślik and Goczek, 2018; Hongdao et al., 2018; Dutta et al., 2017; Saha and Ali, 2017; Gyimah-Brempong and de GyimahBrempong, 2006; Gyimah-Brempong, 2002; Tanzi \& Davoodi, 2002; Mo, 2001; and Mauro, 1995 . Moreover; for control variables, the results show that FDI is significant in column (1) and (3); however, it becomes insignificant 
in columns (2) and (4). Similarly, the variables human capital and global infrastructure are significant in all the equations. The signs of the coefficients are according to the expectation.

The sample of Asian countries' results reveals that the coefficients of debt and debt-square in column (1) and (2) show are slightly insignificant and negative; however, they are significant in column (3) and (4). The coefficients of KCI in column (1) and (2) are both significantly negative; similarly, the interaction term of KCI and debt is also significant. Moreover, the TI and its interaction term are significant, as shown in column (3) and (4). Regarding the control variables, the coefficient of FDI is significant from (1)-(3). However, it becomes insignificant in (4). The coefficient of $\mathrm{HC}$ is significantly positive in all the specifications. The infrastructure variable is statistically insignificant and positive in all the specifications. The possible explanation might be that the infrastructure quality is not satisfactory in Asian countries compared to the advanced countries.

The results of European countries show that from column (1)-(4), the coefficients of debt are significant. Similarly, the coefficients of debt-square are significant in (1), (2), and (3); however, the coefficient is insignificant in (4). For European countries, similar findings are reported by Checherita-Westphal \& Rother $(\underline{2012})^{1}$; and Woo, \& Kumar (2010). The coefficients of KCI, TI, and their interaction with debt are significant in all the specifications. Moreover, FDI is not significant in (1)-(3); however, its coefficient is significant in (4). Similarly, the coefficients of $\mathrm{HC}$ are significant in the first three specifications, but it turns out to be insignificant in the $4^{\text {th }}$ specification. The coefficients of GINFRA are significant in all the specifications.

The results of African countries show that from column (1)-(4), the coefficients of debt and debt-square are significant. The results also indicate that the debt to GDP ratio has a detrimental impact on GDP growth (because it may induce an increase in country risk or higher interest rates). The coefficients of KCI, TI, and their interaction with debt are significant in all the specifications. Moreover, the results of control variables show that FDI is significant in all the specifications. The results for the African sample suggest that Africa became an attractive destination for investors that positively contribute to its economic growth. The coefficients of $\mathrm{HC}$ are not significant in all the equations. This runs contrary to the results of most studies, which suggest that more highly skilled workers are beneficial to economic growth. This might be because, in Africa, economic growth comes mainly from increasing development of the exploitation of natural resources. It is capital intensive and thus does not require more highly skilled workers. ${ }^{2}$ Similarly, the coefficients of GINFRA are significant in (1) and (3), but they are not significant in specifications 2 and 4.

\section{Estimation with more control variables during 1996-2017}

Table 3 reports the result of system GMM. The results in column (1)-(4) under the global sample heading show that the coefficients of debt and debt-square are significantly negative. The coefficients of Kaufmann et al. (2013) corruption index as well TI index are both significant in all the specifications. Similarly, the interaction terms between debt and the corruption indices from column (1)-(4) are significant with correct signs. Moreover; for control variables, the results show that the coefficients of gross capital formation (GCF) are insignificantly negative in all the specifications. However, the coefficients of debt servicing (DS) are significantly negative in all the specifications. Moreover, the coefficients of inflation are not significant in any of the specifications.

The sample of Asian countries' results reveals that the coefficients of debt and debt-square are significantly negative. The coefficients of corruption indices and their interaction terms are significantly negative. Regarding the control variables, the coefficients of gross capital formation (GCF) are slightly insignificant in all the specifications. The coefficients of debt servicing (DS) and inflation (INF) are significantly negative in all the specifications. The result for Europe sample reveals that the coefficients of debt and debt-square are significantly negative. The coefficients of corruption indices and their interaction terms are significantly negative. Regarding the control variables, the coefficients of gross capital formation (GCF) are significant in all the specifications. The coefficients of debt servicing (DS) significantly negative in all the specifications; however, the coefficients are of inflation (INF) is negatively insignificant in all the specifications.

\footnotetext{
1. Regarding the European countries; they find a non-linear impact of debt on growth with a turning point, beyond which the government debt-to-GDP ratio has a deleterious impact on long-term growth, at about $90-100 \%$ of GDP.

${ }^{2}$ Kummer-Noormamode (2014)
} 
Table 2. Growth equation results- system GMM

\begin{tabular}{|c|c|c|c|c|c|c|c|c|c|c|c|c|c|c|c|c|}
\hline & \multicolumn{4}{|c|}{ Full sample } & \multicolumn{4}{|l|}{ Asia } & \multicolumn{4}{|c|}{ Europe } & \multicolumn{4}{|l|}{ Africa } \\
\hline & 1 & 2 & 3 & 4 & 1 & 2 & 3 & 4 & 1 & 2 & 3 & 4 & 1 & 2 & 3 & 4 \\
\hline \multicolumn{17}{|c|}{ Lagged dependent, linear \& Non-linear terms of public debt } \\
\hline $\begin{array}{l}\text { Laged } \\
\text { dep. }\end{array}$ & $\begin{array}{l}0.84 * * * * \\
(0.02)\end{array}$ & $\begin{array}{l}0.84 * * * \\
(0.04)\end{array}$ & $\begin{array}{l}0.87 * * * \\
(0.02)\end{array}$ & $\begin{array}{l}0.87 * * * \\
(0.03)\end{array}$ & $\begin{array}{l}\begin{array}{l}0.8 * * \\
(0.1)\end{array} \\
\end{array}$ & $\begin{array}{l}0.79 * * * \\
(0.24)\end{array}$ & $\begin{array}{l}0.84^{* * * *} \\
(0.12)\end{array}$ & $\begin{array}{l}0.85 * * * \\
(0.08)\end{array}$ & $\begin{array}{l}0.93 \\
(0.78)\end{array}$ & $\begin{array}{l}0.79 \\
(0.66)\end{array}$ & $\begin{array}{l}0.93 * * * \\
(0.04)\end{array}$ & $\begin{array}{l}0.462 * * * \\
(0.222)\end{array}$ & $\begin{array}{l}0.74 \\
(0.6)\end{array}$ & $\begin{array}{l}0.30 \\
(0.25)\end{array}$ & $\begin{array}{l}0.99^{* * *} \\
(0.37)\end{array}$ & $\begin{array}{l}1.0 * * \\
(0.4)\end{array}$ \\
\hline GD & $\begin{array}{l}-0.01 * \\
(0.18)\end{array}$ & $\begin{array}{l}-0.03^{*} \\
(0.02)\end{array}$ & $\begin{array}{l}-0.01 * \\
(0.00)\end{array}$ & $\begin{array}{l}-0.10^{*} \\
(0.06)\end{array}$ & $\begin{array}{l}-0.18 \\
(0.12)\end{array}$ & $\begin{array}{l}-4.65 \\
(3.63)\end{array}$ & $\begin{array}{l}-0.02^{*} \\
(0.011)\end{array}$ & $\begin{array}{l}-0.89^{*} \\
(0.51)\end{array}$ & $\begin{array}{l}-0.22 * * \\
(0.11)\end{array}$ & $\begin{array}{l}-0.12 * * \\
(0.06)\end{array}$ & $\begin{array}{l}-0.23 * * \\
(0.10)\end{array}$ & $\begin{array}{l}-1.203^{* * *} \\
(0.578)\end{array}$ & $\begin{array}{l}-0.03 * * \\
(0.01)\end{array}$ & $\begin{array}{l}-0.5^{* * *} \\
(0.1)\end{array}$ & $\begin{array}{l}-0.08^{* * *} \\
(0.04)\end{array}$ & $\begin{array}{l}-0.2^{* * *} \\
(0.1)\end{array}$ \\
\hline GD-sqrd & $\begin{array}{l}-0.01 * \\
(0.00)\end{array}$ & $\begin{array}{l}-0.01 * \\
(0.01)\end{array}$ & $\begin{array}{l}-0.01 * * \\
(0.00)\end{array}$ & $\begin{array}{l}-0.01 * \\
(0.00)\end{array}$ & $\begin{array}{l}-0.02 \\
(0.01)\end{array}$ & $\begin{array}{l}-0.02^{*} \\
(0.01)\end{array}$ & $\begin{array}{l}-0.01 * \\
(-0.00)\end{array}$ & $\begin{array}{l}-0.01 * \\
(0.00)\end{array}$ & $\begin{array}{l}-0.1 * \\
(0.0)\end{array}$ & $\begin{array}{l}-0.1 * \\
(0.03)\end{array}$ & $\begin{array}{l}-0.003 \\
(0.008)\end{array}$ & $\begin{array}{l}-0.02^{*} \\
(0.009)\end{array}$ & $\begin{array}{l}-0.02 * \\
(0.01)\end{array}$ & $\begin{array}{l}-0.2^{*} \\
(0.1)\end{array}$ & $\begin{array}{l}-0.1 * * * * \\
(0.00)\end{array}$ & $\begin{array}{l}-0.1^{*} \\
(0)\end{array}$ \\
\hline \multicolumn{17}{|c|}{ Control variables } \\
\hline FDI & $\begin{array}{l}0.01^{*} \\
(0.01)\end{array}$ & $\begin{array}{l}0.02 \\
(0.04)\end{array}$ & $\begin{array}{l}0.01 * \\
(0.00)\end{array}$ & $\begin{array}{l}0.01 \\
(0.01)\end{array}$ & $\begin{array}{l}0.15^{*} \\
(0.09)\end{array}$ & $\begin{array}{l}1.56^{*} \\
(0.90)\end{array}$ & $\begin{array}{l}0.09^{*} \\
(0.05)\end{array}$ & $\begin{array}{l}0.143 \\
(0.15)\end{array}$ & $\begin{array}{l}0.002 \\
(0.001)\end{array}$ & $\begin{array}{l}0.44 \\
(0.26)\end{array}$ & $\begin{array}{l}0.01 \\
(0.01)\end{array}$ & $\begin{array}{l}0.267 * * * \\
(0.155)\end{array}$ & $\begin{array}{l}3.41^{* * *} \\
(1.64)\end{array}$ & $\begin{array}{l}0.2^{* * *} \\
(0.1)\end{array}$ & $\begin{array}{l}0.21 * * \\
(0.1)\end{array}$ & $\begin{array}{l}0.21 * * \\
(0.1)\end{array}$ \\
\hline $\mathrm{HC}$ & $\begin{array}{l}0.46^{* * * *} \\
(0.05)\end{array}$ & $\begin{array}{l}0.46^{* * * *} \\
(0.09)\end{array}$ & $\begin{array}{l}0.39^{* * * *} \\
(0.05)\end{array}$ & $\begin{array}{l}0.38^{* * * *} \\
(0.07)\end{array}$ & $\begin{array}{l}0.41^{* *} \\
(0.20)\end{array}$ & $\begin{array}{l}0.48^{*} \\
(0.27)\end{array}$ & $\begin{array}{l}0.39^{*} \\
(0.22)\end{array}$ & $\begin{array}{l}0.38^{* * *} \\
(0.18)\end{array}$ & $\begin{array}{l}0.13^{* * *} \\
(0.06)\end{array}$ & $\begin{array}{l}2.72^{* * *} \\
(1.30)\end{array}$ & $\begin{array}{l}0.15^{*} \\
(0.09)\end{array}$ & $\begin{array}{l}0.993 \\
(0.662)\end{array}$ & $\begin{array}{l}0.24 \\
(0.22)\end{array}$ & $\begin{array}{l}0.93 \\
(0.62)\end{array}$ & $\begin{array}{l}0.7 \\
(0.7)\end{array}$ & $\begin{array}{l}0.93 \\
(0.6)\end{array}$ \\
\hline GINFRA & $\begin{array}{l}0.10^{* * * *} \\
(0.01)\end{array}$ & $\begin{array}{l}0.10^{* * * *} \\
(0.01)\end{array}$ & $\begin{array}{l}0.1 * * * \\
(0.02)\end{array}$ & $\begin{array}{l}0.09 * * * \\
(0.02)\end{array}$ & $\begin{array}{l}0.08 \\
(0.06)\end{array}$ & $\begin{array}{l}0.12 \\
(0.11)\end{array}$ & $\begin{array}{l}0.05 \\
(0.04)\end{array}$ & $\begin{array}{l}0.05 \\
(0.04)\end{array}$ & $\begin{array}{l}0.03^{* *} \\
(0.01)\end{array}$ & $\begin{array}{l}0.39^{* * *} \\
(0.18)\end{array}$ & $\begin{array}{l}0.03^{* * *} \\
(0.01)\end{array}$ & $\begin{array}{l}0.375 * * \\
(0.18)\end{array}$ & $\begin{array}{l}0.38 * * * \\
(0.07)\end{array}$ & $\begin{array}{l}0.25 \\
(0.2)\end{array}$ & $\begin{array}{l}0.34 * * \\
(0.2)\end{array}$ & $\begin{array}{l}0.49 \\
(0.29)\end{array}$ \\
\hline \multicolumn{17}{|c|}{ Corruption indices and their interaction with public debt } \\
\hline KCI & $\begin{array}{l}-0.05^{* * * *} \\
(0.02)\end{array}$ & $\begin{array}{l}-0.03 \\
(0.02)\end{array}$ & & & $\begin{array}{l}-0.03^{*} \\
(0.02)\end{array}$ & $\begin{array}{l}-0.16^{*} \\
(0.09)\end{array}$ & & & $\begin{array}{l}-0.01 * * \\
(0.00)\end{array}$ & $\begin{array}{l}-1.02 * * \\
(0.36)\end{array}$ & & & $\begin{array}{l}-0.82^{* * *} \\
(0.29)\end{array}$ & $\begin{array}{l}-0.1 * * * \\
(0.0)\end{array}$ & & \\
\hline$K C I^{*} G D$ & & $\begin{array}{l}-0.02^{*} \\
(0.01)\end{array}$ & & & & $\begin{array}{l}-5.06^{*} \\
(2.92)\end{array}$ & & & & $\begin{array}{l}-0.15^{*} \\
(0.08)\end{array}$ & & & & $\begin{array}{l}-0.1 * \\
(0.1)\end{array}$ & & \\
\hline TI & & & $\begin{array}{l}-0.17^{*} \\
(0.10)\end{array}$ & $\begin{array}{l}-0.14^{*} \\
(0.08)\end{array}$ & & & $\begin{array}{l}-2.5^{*} \\
(1.45)\end{array}$ & $\begin{array}{l}-0.52^{*} \\
(0.30)\end{array}$ & & & $\begin{array}{l}-0.13^{*} \\
(0.07)\end{array}$ & $\begin{array}{l}-1.128^{*} \\
(0.655)\end{array}$ & & & $\begin{array}{l}-0.7^{*} \\
(0.44)\end{array}$ & $\begin{array}{l}-0.76 * * \\
(0.44)\end{array}$ \\
\hline$T I * G D$ & & & & $\begin{array}{l}-0.17^{*} \\
(0.10)\end{array}$ & & & & $\begin{array}{l}-1.15^{*} \\
(0.66)\end{array}$ & & & & $\begin{array}{l}-1.467 * * * \\
(0.518)\end{array}$ & & & & $\begin{array}{l}-0.03^{* * * *} \\
(0.01)\end{array}$ \\
\hline Obs. & 660 & 660 & 660 & 660 & 300 & 300 & 300 & 300 & 160 & 176 & 160 & 160 & 120 & 120 & 120 & 160 \\
\hline $\begin{array}{l}\text { Hansen } \\
\text { (p-vale) }\end{array}$ & 0.48 & 0.34 & 0.28 & 0.23 & 0.31 & 0.15 & 0.19 & 0.47 & 0.09 & 0.10 & 0.11 & 0.014 & 0.08 & 0.07 & 0.09 & 0.10 \\
\hline $\operatorname{AR}(-2)$ & 0.58 & 0.65 & 0.29 & 0.32 & 0.42 & 0.65 & 0.68 & 0.83 & 0.22 & 0.15 & 0.25 & 0.33 & 0.31 & 0.27 & 0.49 & 0.75 \\
\hline
\end{tabular}

Note: * **, and $* * *$ represents significance at $10 \%, 5 \%$ and $1 \%$ respectively. The coefficient of constant is ignored. Robust standard errors are in parenthesis. GMM results are reported for two-step GMM estimator

The sample of African countries' results reveals that the coefficients of debt and debt-square are significantly negative. The results imply that the debt to GDP ratio has a significant and detrimental impact on GDP growth (because it may induce an increase in country risk or higher interest rates). Similarly, the coefficients of KCI significantly negative in (1) but its coefficient become insignificant in (3); however, its interaction with debt turn out to be significantly negative. The coefficient of TI is significantly negative in the specification (3), but it becomes insignificant in (4); however, its interaction with TI becomes significantly negative. Regarding the control variables, the coefficients of gross capital formation (GCF) are significant in all the specifications. The coefficients of debt servicing (DS) significantly negative in all the specifications. The coefficient of inflation is significantly different from zero and negative, which confirms that a stable macroeconomic environment attracts investors and is favorable for economic growth in Africa.

\section{Estimation with BRI dummy}

To see the impact of Belt \& Road Initiative (BRI) effect on the selected 60 countries closely, we apply fixed and random estimation methodology by incorporating a dummy variable. We assign " 0 " for 2008-2009 and " 1 " for 2013-2017 because in the year 2013 most of the countries joined BRI. Our global sample reduced to 35 countries due to non-availability of data and late joining of some countries. For robustness checking, we incorporate additional control variables.

Table 4 reports the results of the fixed-effect model. Total of 12 specifications is estimated. The linear and nonlinear terms of public debt are significantly positive in all the specifications. Similarly, the KCI and TI are significantly negative in all the specifications. The coefficients of the shadow economy and its interaction with public debt are significantly negative in all the specifications. It shows that the size of the shadow economy and economic growth are negatively correlated. Our variable of interest, i.e., the BRI dummy, is significant and has a positive impact on economic growth. The control variables show mix results, i.e., FDI and GINFRA are significantly positive, but HC becomes insignificant. Similarly, gross capital formation is significantly positive in all the equations, which shows that investment plays a positive role in economic growth. Similarly, the coefficients of debt servicing are significantly negative, but inflation becomes insignificant in all the specification though its coefficients are negative. 
Table 3. Growth equation results- system GMM

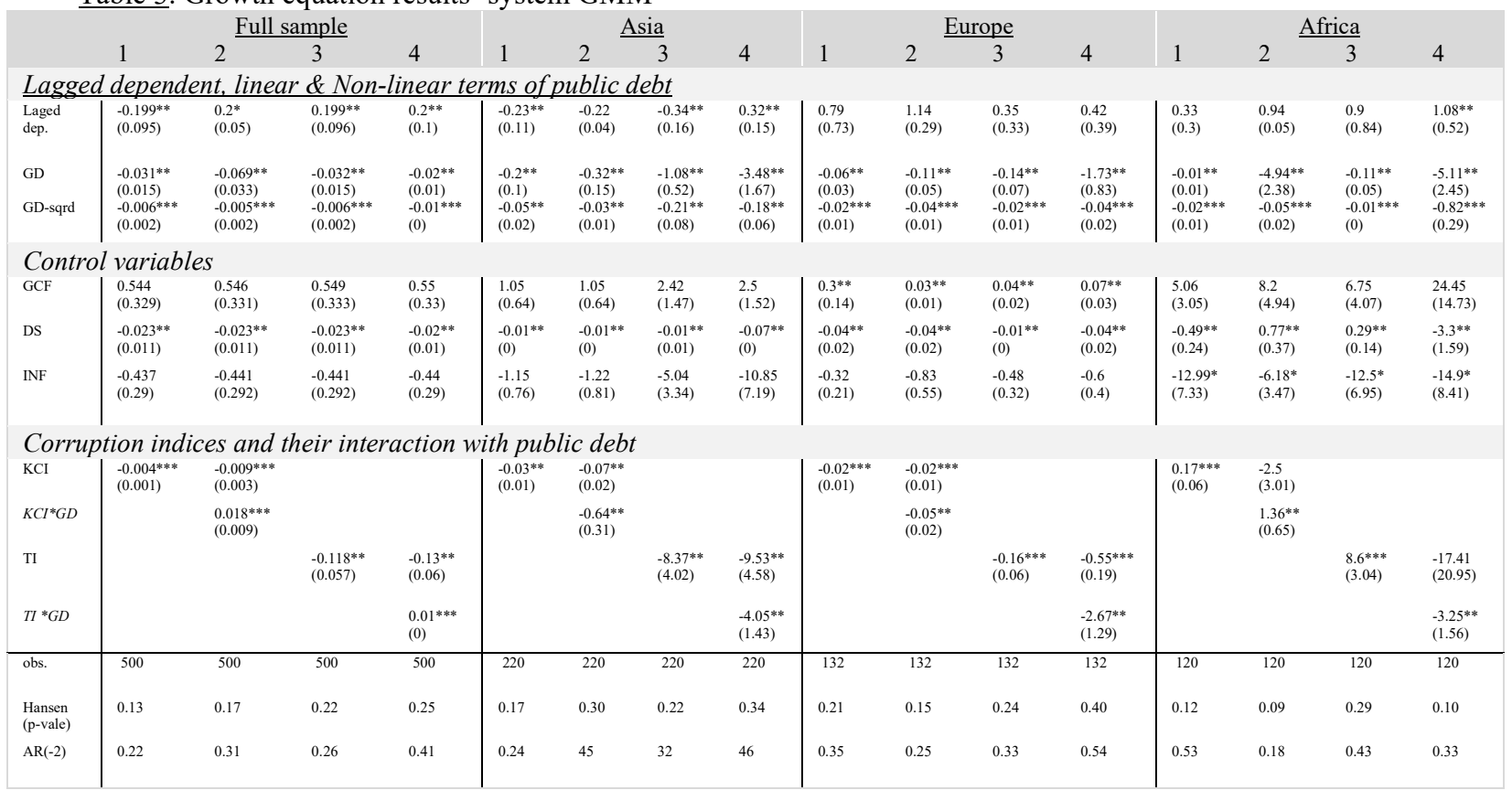

Note: *, **, and *** represents significance at 10\%,5\% and 1\% respectively. The coefficient of constant is ignored. Robust standard errors are in parenthesis. GMM results are reported for two-step GMM estimator

\section{Estimation of Gini by quantile regression approach}

Table 5 and Table 6 present results for each measure of public debt and corruption for the full sample of countries. Column (1) shows the fixed effect estimation. From columns (2) to (6), we report results for the 10, 25, 50, 75, and 90 percent quantile. The equality test is shown in column (7). ${ }^{1}$ Robust standard errors for the fixed effects estimates and the QR results from the 1000 bootstrapping repetitions are reported to obtain robust heteroskedasticity estimates. The results show that all the measures of public debt, the square of public debt, and debt servicing have a statistically insignificant. The results imply that public debt has no effect on income distribution. These findings are following Akram (2016); Prechel(1985). The transmission channels that can affect the income distribution are complicated (Blejer and Guerrero 1990). The impacts of the composition of aggregate policy packages may differ from individual variables. The impact of corruption on inequality is significantly positive-i.e., high and rising corruption increase income inequality and poverty by reducing the formation of human capital, the progressively of tax system, the effectiveness of social spending, by perpetuating unequal distribution of assets owned, and reducing economic growth. The findings are consistent with Gupta (1998). The coefficients' signs of public debt in fixed effect and QR are coherent. Lastly, the equality test suggests that null hypothesis may be rejected in favor of alternative hypothesis that $\mathrm{QR}$ coefficients are not equal.

The results in Table 5 suggests that trade openness promotes inequality. The findings are consistent with Altunbas \& Thornton (2019); Akram (2016); Lundberg and Lyn (1999). Economic openness through capital inflows, FDI, and trade are important elements for economic growth, but these factors enhance the level of inequalities. Our finding support the view that globalization increase income inequalities. Similarly, the human capital deteriorates due to the increased corruption, which leads to an increase in income inequality. The findings are consistent with Gupta (1998).Per capita GDP appears to have a significant negative impact on income distribution. Altunbaş\& Thornton (2019); Akram (2016); Page (2006); and Dollar \&Kraay(2003) also support that the income inequality can be reduced by enhancing per capita GDP and is helpful for the poor. The inequalities can be reduced with an increase in per capita GDP. Higher economic growth can also help in increasing public investments and revenues, thereby, brings poor to economic mainstream.

\footnotetext{
${ }^{1}$ The equality test is conducted for the purpose that the slope coefficients of the regression quantile are all the same.
} 
Table 4. Growth equation results- fixed \& random effect

\begin{tabular}{|c|c|c|c|c|c|c|c|c|c|c|c|c|}
\hline & 1 & 2 & 3 & 4 & 5 & 6 & 7 & 8 & 9 & 10 & 11 & 12 \\
\hline \multicolumn{13}{|c|}{ Linear \& Non-linear terms of public debt } \\
\hline $\begin{array}{l}\text { GD } \\
\text { GD-sqrd }\end{array}$ & $\begin{array}{l}-0.03 \\
(0.03) \\
-0.02 * * * \\
(0)\end{array}$ & $\begin{array}{l}-0.07^{* *} \\
(0.03) \\
-0.05^{* *} \\
(0.03)\end{array}$ & $\begin{array}{l}-0.03 * * \\
(0.02) \\
-0.04 * * \\
(0.02)\end{array}$ & $\begin{array}{l}-0.06 * * \\
(0.03) \\
-0.04 * * \\
(0.02)\end{array}$ & $\begin{array}{l}-0.07^{* *} \\
(0.04) \\
-0.05^{* *} \\
(0.03)\end{array}$ & $\begin{array}{l}-0.06^{* *} \\
(0.03) \\
-0.02^{* *} \\
(0.01)\end{array}$ & $\begin{array}{l}-0.03 \\
(0.02) \\
-0.02 * * \\
(0.01)\end{array}$ & $\begin{array}{l}-0.11^{* *} \\
(0.05) \\
-0.04^{* *} \\
(0.02)\end{array}$ & $\begin{array}{l}-0.05^{* *} \\
(0.02) \\
-0.01 * * \\
(0.00)\end{array}$ & $\begin{array}{l}-0.07^{* *} \\
(0.03) \\
-0.05^{* *} \\
(0.02)\end{array}$ & $\begin{array}{l}-0.05^{* *} \\
(0.02) \\
-0.03^{* *} \\
(0.02)\end{array}$ & $\begin{array}{l}-0.05^{* *} \\
(0.02) \\
-0.03^{*} \\
(0.02)\end{array}$ \\
\hline \multicolumn{13}{|c|}{ Control variables } \\
\hline $\begin{array}{l}\text { FDI } \\
\text { HC } \\
\text { GINFRA }\end{array}$ & $\begin{array}{l}0.02^{* * *} \\
(0.01) \\
0.14 \\
(0.08) \\
0.09^{* *} \\
(0.04)\end{array}$ & $\begin{array}{l}0.02 * * * \\
(0.01) \\
0.13 \\
(0.08) \\
0.09 * * \\
(0.04)\end{array}$ & $\begin{array}{l}0.02 * * * \\
(0.01) \\
0.14 \\
(0.09) \\
0.09 * * \\
(0.05)\end{array}$ & $\begin{array}{l}0.02^{* * *} \\
(0.00) \\
0.142 \\
(0.08) \\
0.09^{* *} \\
(0.04)\end{array}$ & $\begin{array}{l}0.02^{* * *} \\
(0.01) \\
0.15 \\
(0.09) \\
0.1 * * \\
(0.05)\end{array}$ & $\begin{array}{l}0.02 * * * \\
(0.01) \\
0.14 \\
(0.09) \\
0.11^{* *} \\
(0.05)\end{array}$ & & & & & & \\
\hline \multicolumn{13}{|c|}{ Inclusion of more control variables } \\
\hline $\begin{array}{l}\text { GCF } \\
\text { DS } \\
\text { INF }\end{array}$ & & & & & & & $\begin{array}{l}0.3^{* * *} \\
(0.11) \\
-0.03^{* *} \\
(0.01) \\
-0.37 \\
(0.26)\end{array}$ & $\begin{array}{l}0.27^{* * *} \\
(0.09) \\
-0.04 * * \\
(0.02) \\
-0.02 \\
(0.01)\end{array}$ & $\begin{array}{l}0.26^{* * *} \\
(0.09) \\
-0.04 * * \\
(0.02) \\
-0.15 \\
(0.1)\end{array}$ & $\begin{array}{l}0.32^{* * *} \\
(0.11) \\
-0.03^{* *} \\
(0.02) \\
-0.4 \\
(0.28)\end{array}$ & $\begin{array}{l}0.25^{* * *} \\
(0.09) \\
-0.04^{* *} \\
(0.02) \\
-0.28 \\
(0.19)\end{array}$ & $\begin{array}{l}0.23^{* * *} \\
(0.08) \\
-0.04 * * \\
(0.02) \\
-0.62 \\
(0.42)\end{array}$ \\
\hline \multicolumn{13}{|c|}{ Corruption indices, shadow economy, and their interaction with public debt } \\
\hline $\begin{array}{l}\mathrm{KCI} \\
K C I^{*} G D\end{array}$ & $\begin{array}{l}-0.04^{* *} \\
(0.02)\end{array}$ & $\begin{array}{l}-0.03^{* *} \\
(0.01) \\
-0.02^{* * *} \\
(0.01)\end{array}$ & & & & & $\begin{array}{l}-0.04 * * \\
(0.02)\end{array}$ & $\begin{array}{l}-0.07 * * \\
(0.03) \\
-0.02 * * *\end{array}$ & & & & \\
\hline $\mathrm{TI}$ & & & $\begin{array}{l}-0.05^{* *} \\
(0.02)\end{array}$ & $\begin{array}{c}-0.08^{*} \\
(0.05)\end{array}$ & & & & & $\begin{array}{l}-0.02 * * \\
(0.01)\end{array}$ & $\begin{array}{c}-0.1 * * \\
(0.05)\end{array}$ & & \\
\hline$T I * G D$ & & & & $\begin{array}{l}-0.06 * * * \\
(0.02)\end{array}$ & & & & & & $\begin{array}{l}-0.04 * * \\
(0.02)\end{array}$ & & \\
\hline Shadow & & & & & $\begin{array}{l}-0.24 * * \\
(0.12)\end{array}$ & $\begin{array}{l}-0.22 * * \\
(0.11)\end{array}$ & & & & & $\begin{array}{l}-0.18^{* *} \\
(0.09)\end{array}$ & $\begin{array}{l}-0.19 * * \\
(0.09)\end{array}$ \\
\hline Shadow $* G D$ & & & & & & $\begin{array}{l}-1.97 * * \\
(0.69)\end{array}$ & & & & & & $\begin{array}{l}-1.02 \\
(0.65)\end{array}$ \\
\hline \multicolumn{13}{|c|}{ Inclusion of BRI dummy } \\
\hline$D D$ & $\begin{array}{l}0.01 * * * \\
(0.00)\end{array}$ & $\begin{array}{l}0.01 * * * \\
(0.00)\end{array}$ & $\begin{array}{l}0.01^{* * *} \\
(0.00)\end{array}$ & $\begin{array}{l}0.01 * * * \\
(0.00)\end{array}$ & $\begin{array}{l}0.02^{* * *} \\
(0.01)\end{array}$ & $\begin{array}{l}0.02 * * * \\
(0.00)\end{array}$ & $\begin{array}{l}0.01 * * * \\
(0.00)\end{array}$ & $\begin{array}{l}0.01^{* * *} \\
(0.00)\end{array}$ & $\begin{array}{l}0.01 * * \\
(0.01)\end{array}$ & $\begin{array}{l}0.02^{* * *} \\
(0.00)\end{array}$ & $\begin{array}{l}0.02 * * \\
(0.01)\end{array}$ & $\begin{array}{l}0.02 * * * \\
(0.00)\end{array}$ \\
\hline obs. & 332 & 332 & 332 & 332 & 332 & 332 & 250 & 250 & 250 & 250 & 250 & 250 \\
\hline $\begin{array}{l}\text { Hausman } \\
\text { (p-vale) }\end{array}$ & 0.002 & 0.005 & 0.003 & 0.009 & 0.000 & 0.000 & 0.103 & 0.1048 & 0.103 & 0.104 & 0.0440 & 0.064 \\
\hline
\end{tabular}

Note: $* * *$, and $* * *$ represents significance at $10 \%, 5 \%$ and $1 \%$ respectively. The coefficient of constant is ignored. Robust standard errors are in parenthesis

Of the other explanatory variables in Table 6; urbanization has a positive and significant impact on income distribution. The results are consistent with the hypothesis that excessive urbanization leads to worsen the workers health and increase unemployment (Oyvat, 2016; Harris-Todaro (1970). The situation leads to reduce the productivity and income of the poor. Similarly, government expenditure has also a significant positive impact on income inequality, which is consistent with the findings of Altunbaş \& Thornton (2019). Government expenditure may be a poor proxy for social spending. The government expenditures aim to reduce income inequalities, but it may be possible that most spending on transfers is captured by the middle class (Milanovic, 1994; Davoodi et al., 2003). The argument is also consistent with the quantile results. The coefficients inflation is not statistically significant. 
Table 5. Public debt and income inequality: dependent variable Gini coefficient.

\begin{tabular}{|c|c|c|c|c|c|c|c|c|c|c|c|c|c|c|}
\hline & (1) & (2) & (3) & (4) & (5) & (6) & (7) & (8) & (9) & (10) & (11) & (12) & (13) & (14) \\
\hline & FE & Q10 & Q25 & Q50 & Q75 & Q90 & $\begin{array}{l}\text { Eq. } \\
\text { test }\end{array}$ & FE & Q10 & Q25 & Q50 & Q75 & Q90 & $\begin{array}{l}\text { Eq. } \\
\text { test }\end{array}$ \\
\hline \multicolumn{15}{|c|}{ Linear \& Non-linear terms of public debt } \\
\hline $\begin{array}{l}\text { GD } \\
\text { GD- } \\
\text { sqrd }\end{array}$ & $\begin{array}{l}-0.1 \\
(0.1) \\
-0.01 \\
(0.02)\end{array}$ & $\begin{array}{l}-0.2 \\
(0.2) \\
-0.07 \\
(0.06)\end{array}$ & $\begin{array}{l}-0.16 \\
(0.14) \\
-0.04 \\
(0.04)\end{array}$ & $\begin{array}{l}-0.23 \\
(0.19) \\
-0.04 \\
(0.03)\end{array}$ & $\begin{array}{l}-0.01 \\
(0.02) \\
0.06 \\
(0.07)\end{array}$ & $\begin{array}{l}-0.53 \\
(0.45) \\
0.04 \\
(0.04)\end{array}$ & $\begin{array}{l}0.51 \\
(0.72) \\
1.83 \\
(0.12)\end{array}$ & $\begin{array}{l}-0.05 \\
(0.04) \\
-0.05 \\
(0.05)\end{array}$ & $\begin{array}{l}-0.09 \\
(0.08) \\
-0.06 \\
(0.05)\end{array}$ & $\begin{array}{l}-0.07 \\
(0.06) \\
-0.04 \\
(0.05)\end{array}$ & $\begin{array}{l}-0.14 \\
(0.12) \\
-0.04 \\
(0.03)\end{array}$ & $\begin{array}{l}-0.08 \\
(0.07) \\
-0.01 \\
(0.01)\end{array}$ & $\begin{array}{l}-0.01 \\
(0.01) \\
-0.02 \\
(0.02)\end{array}$ & $\begin{array}{l}1.02 \\
(0.39) \\
0.75 \\
(0.56)\end{array}$ \\
\hline \multicolumn{15}{|c|}{ Inclusion of control variables } \\
\hline OPEN & $\begin{array}{l}0.01 * \\
(0)\end{array}$ & $\begin{array}{l}0.02^{*} \\
(0.01)\end{array}$ & $\begin{array}{l}0.08 * * \\
(0.03)\end{array}$ & $\begin{array}{l}0.11 * * \\
(0.04)\end{array}$ & $\begin{array}{l}0.29 * * \\
(0.11)\end{array}$ & $\begin{array}{l}0.16^{* *} \\
(0.06)\end{array}$ & $\begin{array}{l}1.13 \\
(0.34)\end{array}$ & $\begin{array}{l}0.01^{*} \\
(0.01)\end{array}$ & $\begin{array}{l}0.01 * * \\
(0)\end{array}$ & $\begin{array}{l}0.02 * * \\
(0.01)\end{array}$ & $\begin{array}{l}0.1 \\
(0.04)\end{array}$ & $\begin{array}{l}0.24 * \\
(0.1)\end{array}$ & $\begin{array}{l}0.14 \\
(0.05)\end{array}$ & $\begin{array}{l}4.67 \\
(0.001)\end{array}$ \\
\hline $\mathrm{HC}$ & $\begin{array}{l}-0.09^{*} \\
(0.05)\end{array}$ & $\begin{array}{l}-0.12 * \\
(0.07)\end{array}$ & $\begin{array}{l}-0.1^{*} \\
(0.06)\end{array}$ & $\begin{array}{l}-0.18^{*} \\
(0.10)\end{array}$ & $\begin{array}{l}-0.17^{*} \\
(0.09)\end{array}$ & $\begin{array}{l}-0.21^{*} \\
(0.11)\end{array}$ & $\begin{array}{l}1.78 \\
(0.13)\end{array}$ & $\begin{array}{l}-0.09^{*} \\
(0.06)\end{array}$ & $\begin{array}{l}-0.05^{*} \\
(0.03)\end{array}$ & $\begin{array}{l}-0.06^{*} \\
(0.03)\end{array}$ & $\begin{array}{l}-0.16^{*} \\
(0.09)\end{array}$ & $\begin{array}{l}-0.13^{*} \\
(0.07)\end{array}$ & $\begin{array}{l}-0.23^{*} \\
(0.12)\end{array}$ & $\begin{array}{l}1.32 \\
(0.263)\end{array}$ \\
\hline GDPPC & $\begin{array}{l}-0.01^{*} \\
(0)\end{array}$ & $\begin{array}{l}-0.13^{*} \\
(0.06)\end{array}$ & $\begin{array}{l}-0.09 * * \\
(0.04)\end{array}$ & $\begin{array}{l}-0.1 * * \\
(0.04)\end{array}$ & $\begin{array}{l}-0.01^{* *} \\
(0.01)\end{array}$ & $\begin{array}{l}-0.01 * * \\
(0)\end{array}$ & $\begin{array}{l}2.02 \\
(0.09)\end{array}$ & $\begin{array}{l}0.01^{*} \\
(0.01)\end{array}$ & $\begin{array}{l}-0.1 * * \\
(0.04)\end{array}$ & $\begin{array}{l}-0.11^{*} \\
(0.05)\end{array}$ & $\begin{array}{l}-0.1^{* *} \\
(0.04)\end{array}$ & $\begin{array}{l}-0.03^{* *} \\
(0.01)\end{array}$ & $\begin{array}{l}-0.2 \\
(0.05)\end{array}$ & $\begin{array}{l}2.10 \\
(0.081)\end{array}$ \\
\hline \multicolumn{15}{|c|}{ Corruption indices and their interaction with public debt } \\
\hline $\mathrm{KCI}$ & $\begin{array}{l}0.18^{*} \\
(0.1)\end{array}$ & $\begin{array}{l}0.09 * * \\
(0.04)\end{array}$ & $\begin{array}{l}0.1 * * \\
(0.05)\end{array}$ & $\begin{array}{l}0.06^{* *} \\
(0.03)\end{array}$ & $\begin{array}{l}0.1 * * \\
(0.05)\end{array}$ & $\begin{array}{l}0.11 * * \\
(0.05)\end{array}$ & $\begin{array}{l}0.21 \\
(0.93)\end{array}$ & & & & & & & \\
\hline $\begin{array}{l}K C I^{*} \\
G D\end{array}$ & $\begin{array}{l}0.04 * * \\
(0.02)\end{array}$ & $\begin{array}{l}0.04^{*} \\
(0.02)\end{array}$ & $\begin{array}{l}0.03^{*} \\
(0.02)\end{array}$ & $\begin{array}{l}0.07 * \\
(0.04)\end{array}$ & $\begin{array}{l}0.04 * \\
(0.02)\end{array}$ & $\begin{array}{l}0.49^{*} \\
(0.27)\end{array}$ & $\begin{array}{l}1.39 \\
(0.23)\end{array}$ & & & & & & & \\
\hline TI & & & & & & & & $\begin{array}{l}0.2^{*} \\
(0.11)\end{array}$ & $\begin{array}{l}0.01 * * \\
(0)\end{array}$ & $\begin{array}{l}0.06^{*} \\
(0.03)\end{array}$ & $\begin{array}{l}0.38^{*} \\
(0.19)\end{array}$ & $\begin{array}{l}0.18 \\
(0.09)\end{array}$ & $\begin{array}{l}0.56^{* * * *} \\
(0.27)\end{array}$ & $\begin{array}{l}0.26 \\
(0.90)\end{array}$ \\
\hline $\begin{array}{l}T I * \\
G D\end{array}$ & & & & & & & & $\begin{array}{l}0.01^{*} \\
(0.01)\end{array}$ & $\begin{array}{l}0.02 * \\
(0.01)\end{array}$ & $\begin{array}{l}0.01 * \\
(0.01)\end{array}$ & $\begin{array}{l}0.02 * \\
(0.01)\end{array}$ & $\begin{array}{l}0.01 * * \\
(0)\end{array}$ & $\begin{array}{l}0.01 * * \\
(0)\end{array}$ & $\begin{array}{l}1.35 \\
(0.21)\end{array}$ \\
\hline obs. & 639 & 639 & 639 & 639 & 639 & 639 & & 639 & 639 & 639 & 639 & 639 & 639 & \\
\hline $\mathrm{R}^{2}$ & 0.037 & 0.178 & 0.118 & 0.084 & 0.045 & 0.067 & & 0.058 & 0.162 & 0.108 & 0.0872 & 0.0368 & 0.0598 & \\
\hline
\end{tabular}

Note: $* * *$, and $* * *$ represents significance at $10 \%, 5 \%$ and $1 \%$ respectively. The coefficient of constant is ignored. Robust standard errors are in parenthesis 
Table 6. Public debt and income inequality: dependent variable Gini coefficient. (more control variables)

\begin{tabular}{|c|c|c|c|c|c|c|c|c|c|c|c|c|c|c|}
\hline & (1) & (2) & (3) & (4) & (5) & (6) & (7) & (8) & (9) & (10) & (11) & (12) & (13) & (14) \\
\hline & $\begin{array}{l}\text { Fixed } \\
\text { Effect }\end{array}$ & Q10 & Q25 & Q50 & Q75 & Q90 & $\begin{array}{l}\text { Eq. } \\
\text { test }\end{array}$ & $\begin{array}{l}\text { Fixed } \\
\text { Effect }\end{array}$ & Q10 & Q25 & Q50 & Q75 & Q90 & Eq. test \\
\hline \multicolumn{15}{|c|}{ Linear \& Non-linear terms of public debt } \\
\hline $\begin{array}{l}\text { GD } \\
\text { GD-sqrd }\end{array}$ & $\begin{array}{c}-0.14 \\
(0.13) \\
-0.02 \\
(0.02)\end{array}$ & $\begin{array}{l}-0.36 \\
(0.29) \\
-0.08 \\
(0.07)\end{array}$ & $\begin{array}{l}-0.43 \\
(0.42) \\
-0.08 \\
(0.08)\end{array}$ & $\begin{array}{l}-0.37 \\
(0.34) \\
-0.05 \\
(0.04)\end{array}$ & $\begin{array}{l}-0.06 \\
(0.06) \\
-0.04 \\
(0.04)\end{array}$ & $\begin{array}{l}-0.2 \\
(0.2) \\
-0.06 \\
(0.05)\end{array}$ & $\begin{array}{l}3.37 \\
(0.01) \\
0.76 \\
(0.55)\end{array}$ & $\begin{array}{l}-0.06 \\
(0.05) \\
-0.01 \\
(0.01)\end{array}$ & $\begin{array}{l}-0.17 \\
(0.15) \\
-0.09 \\
(0.08)\end{array}$ & $\begin{array}{l}-0.24 \\
(0.21) \\
-0.07 \\
(0.06)\end{array}$ & $\begin{array}{l}-0.18 \\
(0.17) \\
-0.03 \\
(0.03)\end{array}$ & $\begin{array}{l}-0.05 \\
(0.04) \\
-0.01 \\
(0.01)\end{array}$ & $\begin{array}{l}-0.07 \\
(0.07) \\
-0.01 \\
(0.01)\end{array}$ & $\begin{array}{l}1.13 \\
(0.37) \\
0.89 \\
(0.60)\end{array}$ \\
\hline \multicolumn{15}{|c|}{ Inclusion of more control variables } \\
\hline URBAN & $\begin{array}{l}0.34^{*} \\
(0.19)\end{array}$ & $\begin{array}{l}0.2^{*} \\
(0.11)\end{array}$ & $\begin{array}{l}0.16^{*} \\
(0.09)\end{array}$ & $\begin{array}{l}0.35^{*} \\
(0.2)\end{array}$ & $\begin{array}{l}1.37 * \\
(0.77)\end{array}$ & $\begin{array}{l}1.65^{*} \\
(0.93)\end{array}$ & $\begin{array}{l}1.13 \\
(0.34)\end{array}$ & $\begin{array}{l}0.32^{*} \\
(0.18)\end{array}$ & $\begin{array}{l}0.42^{*} \\
(0.24)\end{array}$ & $\begin{array}{l}0.02 * \\
(0.01)\end{array}$ & $\begin{array}{l}0.34^{*} \\
(0.19)\end{array}$ & $\begin{array}{l}-0.89^{*} \\
(0.5)\end{array}$ & $\begin{array}{l}1.59^{*} \\
(0.89)\end{array}$ & $\begin{array}{l}4.76 \\
(0.002)\end{array}$ \\
\hline DS & $\begin{array}{l}-0.01 \\
(0.01)\end{array}$ & $\begin{array}{l}-0.02 \\
(0.01)\end{array}$ & $\begin{array}{l}-0.02 \\
(0.01)\end{array}$ & $\begin{array}{l}-0.03 \\
(0.02)\end{array}$ & $\begin{array}{l}-0.03 \\
(0.02)\end{array}$ & $\begin{array}{l}-0.09 \\
(0.06)\end{array}$ & $\begin{array}{l}1.06 \\
(0.36)\end{array}$ & $\begin{array}{l}-0.01 \\
(0.01)\end{array}$ & $\begin{array}{l}-0.02 \\
(0.01)\end{array}$ & $\begin{array}{l}-0.02 \\
(0.01)\end{array}$ & $\begin{array}{l}-0.01 \\
(0.01)\end{array}$ & $\begin{array}{l}0.01 \\
(0.01)\end{array}$ & $\begin{array}{l}-0.03 \\
(0.02)\end{array}$ & $\begin{array}{l}1.44 \\
(0.30)\end{array}$ \\
\hline INF & $\begin{array}{l}0.62 \\
(0.55)\end{array}$ & $\begin{array}{l}1.57 \\
(1.08)\end{array}$ & $\begin{array}{l}1.96 \\
(1.32)\end{array}$ & $\begin{array}{l}2.57 \\
(1.75)\end{array}$ & $\begin{array}{l}2.61 \\
(2.21)\end{array}$ & $\begin{array}{l}3.83 \\
(2.77)\end{array}$ & $\begin{array}{l}1.54 \\
(0.17)\end{array}$ & $\begin{array}{l}1.66 \\
(1.2)\end{array}$ & $\begin{array}{l}2.18 \\
(1.58)\end{array}$ & $\begin{array}{l}1.07 \\
(0.77)\end{array}$ & $\begin{array}{l}1.96 \\
(1.42)\end{array}$ & $\begin{array}{l}2.19 \\
(1.59)\end{array}$ & $\begin{array}{l}4.76 \\
(3.67)\end{array}$ & $\begin{array}{l}2.12 \\
(0.09)\end{array}$ \\
\hline GE & $\begin{array}{l}0.05^{*} \\
(0.03)\end{array}$ & $\begin{array}{l}0.34^{*} \\
(0.19)\end{array}$ & $\begin{array}{l}0.21^{*} \\
(0.12)\end{array}$ & $\begin{array}{l}0.23 \\
(0.20)\end{array}$ & $\begin{array}{l}0.17 \\
(0.15)\end{array}$ & $\begin{array}{l}0.38^{*} \\
(0.21)\end{array}$ & $\begin{array}{l}3.38 \\
(0.01)\end{array}$ & $\begin{array}{l}-0.01 * \\
(0.01)\end{array}$ & $\begin{array}{l}0.18^{*} \\
(0.1)\end{array}$ & $\begin{array}{l}0.07 * \\
(0.04)\end{array}$ & $\begin{array}{l}0.15^{*} \\
(0.08)\end{array}$ & $\begin{array}{l}0.33^{*} \\
(0.19)\end{array}$ & $\begin{array}{l}0.55^{*} \\
(0.31)\end{array}$ & $\begin{array}{l}1.54 \\
(0.17)\end{array}$ \\
\hline \multicolumn{15}{|c|}{$\underline{\text { Corruption indices and their interaction with public debt }}$} \\
\hline $\mathrm{KCI}$ & $\begin{array}{l}0.17 * * \\
(0.08)\end{array}$ & $\begin{array}{l}0.4^{* *} \\
(0.19)\end{array}$ & $\begin{array}{l}0.31^{* *} \\
(0.15)\end{array}$ & $\begin{array}{l}0.23 * * \\
(0.11)\end{array}$ & $\begin{array}{l}0.17 * * \\
(0.08)\end{array}$ & $\begin{array}{l}0.32 * * \\
(0.15)\end{array}$ & $\begin{array}{l}2.28 \\
(0.06)\end{array}$ & & & & & & & \\
\hline$K C I^{*} G D$ & $\begin{array}{l}0.06^{* *} \\
(0.03)\end{array}$ & $\begin{array}{l}0.08 * * \\
(0.04)\end{array}$ & $\begin{array}{l}0.12 * * \\
(0.06)\end{array}$ & $\begin{array}{l}0.11^{* *} \\
(0.05)\end{array}$ & $\begin{array}{l}0.02 * * \\
(0.01)\end{array}$ & $\begin{array}{l}0.08^{* *} \\
(0.04)\end{array}$ & $\begin{array}{l}5.21 \\
(0.00)\end{array}$ & & & & & & & \\
\hline TI & & & & & & & & $\begin{array}{l}-0.02 * * \\
(0.01)\end{array}$ & $\begin{array}{l}0.07 * * \\
(0.03)\end{array}$ & $\begin{array}{l}0.95 * * \\
(0.46)\end{array}$ & $\begin{array}{l}0.7 * * \\
(0.33)\end{array}$ & $\begin{array}{l}0.32 * * \\
(0.15)\end{array}$ & $\begin{array}{l}0.61 * * \\
(0.29)\end{array}$ & $\begin{array}{l}2.27 \\
(0.05)\end{array}$ \\
\hline$T I * G D$ & & & & & & & & $\begin{array}{l}-0.01^{* *} \\
(0.01)\end{array}$ & $\begin{array}{l}0.01 * * \\
(0)\end{array}$ & $\begin{array}{l}0.01 * * \\
(0)\end{array}$ & $\begin{array}{l}0.01 * * \\
(0.01)\end{array}$ & $\begin{array}{l}0.01 * * \\
(0)\end{array}$ & $\begin{array}{l}0.02 * * \\
(0.01)\end{array}$ & $\begin{array}{l}1.46 \\
(0.23)\end{array}$ \\
\hline obs. & 529 & 529 & 529 & 529 & 529 & 529 & & 0.0405 & 529 & 529 & 529 & 529 & 529 & \\
\hline $\mathrm{R}^{2}$ & 0.0597 & 0.2772 & 0.1568 & 0.0627 & 0.0819 & 0.2612 & & 0.0405 & 0.201 & 0.085 & 0.048 & 0.0556 & 0.231 & \\
\hline
\end{tabular}

\section{Conclusions and policy implications}

High debt to GDP means the collapse of economic growth and increase income inequality. The impact of public debt on growth is so much dangerous than unemployment even in time of recession, and it leads to policies like austerity. Therefore, our study aims to analyze the role of public debt in economic growth and income inequality in the presence of corruption in Belt \& Road (BRI) countries. The findings of the study show that public debt has a negative effect on per capita GDP growth for both grouped and ungrouped data. Similarly, the impact of corruption and its interaction with public debt is negative for economic growth. Moreover, we conclude that the addition of more control variables does not affect the debt and growth relationship.

Furthermore, we conclude that the Belt \& Road initiative plays a positive role in enhancing economic performance for the member countries. Similarly, we conclude that corruption plays a positive role in income inequality. The interaction of corruption with public debt also strengthens the view that due to rampant corruption and excessive public debt in the BRI countries more widened the gap between rich and poor.

Another important conclusion is that debt servicing affect economic growth negatively. However, FDI, human capital, infrastructure, and gross capital formation have a favorable effect on economic growth. We find evidence of an unfavorable effect of government expenditure, trade openness, and urbanization on income inequality. However, we find that per capita GDP and human capital favorably affect income distribution. 


\section{References}

Abbas, S. M. (2007) Public Domestic Debt and Growth in LICs (Draft doctoral thesis). University of Oxford, Oxford. Retrieved from http://users.ox.ac.uk/ hert1734/Public\%20domestic\% $\% 20$ debt $\% 20$ and\%20growth.pdf

Abed, G. T., \&Davoodi, H. R. (2000). Corruption, Structural Reforms, and Economic Performance in the Transition Economies. IMF Working Papers, 00(132), 1. doi:10.5089/9781451855371.001

Akram, N. (2016). Public debt and pro-poor economic growth evidence from South Asian countries. Economic Research-EkonomskaIstraživanja, 29(1), 746-757. doi:10.1080/1331677x.2016.1197550

Al-Marhubi, F. A. (2000). Corruption and inflation. Economics Letters, 66(2), 199-202. doi:10.1016/s01651765(99)00230-X

Altunbaş, Y., \& Thornton, J. (2019). The impact of financial development on income inequality: A quantile regression approach. Economics Letters, 175, 51-56. doi:10.1016/j.econlet.2018.12.030

Arellano, M., \&Bover, O. (1995). Another look at the instrumental variable estimation of error-components models. Journal of Econometrics, 68(1), 29-51. doi:10.1016/0304-4076(94)01642-d

Baltagi, B. H. (2005). Econometric Analysis of Panel Data (3rd ed.). West Sussex: John Wiley \& Sons.

Barro, R. J. and Sala-i-Martin, X. (2004), Economic Growth. 2nd ed. s.1.: MIT Press.

Blejer, M. I., \& Guerrero, I. (1990). The Impact of Macroeconomic Policies on Income Distribution: An Empirical Study of the Philippines. The Review of Economics and Statistics, 72(3), 414. doi:10.2307/2109349

Blundell, R., \& Bond, S. (1998). Initial conditions and moment restrictions in dynamic panel data models. Journal of Econometrics, 87(1), 115-143. doi:10.1016/s0304-4076(98)00009-8

Brunetti, A., Kisunko, G., \&Weder, B. (1998). Credibility of Rules and Economic Growth: Evidence from a Worldwide Survey of the Private Sector. The World Bank Economic Review, 12(3), 353-384. doi:10.1093/wber/12.3.353

Buchanan, J. M. (1966). The ICons of Public Debt. The Journal of Finance, 21(3), 544-546. doi:10.1111/j.1540-6261.1966.tb00256.x

Burnside, C. M., \& Dollar, D. (2000). Aid, Policies, and Growth. American Economic Review, 90(4), 847-868. doi:10.1257/aer.90.4.847

Carkovic, M., and Levine, R. 2005. Does foreign direct investment accelerate economic growth? In Does foreign direct investment promote development? ed. T. H. Moran, E. M. Graham, and M. Blomström, 195-220. Washington, DC: Institute for International Economics.

Chen, C., Yao, S., Hu, P., \& Lin, Y. (2017). Optimal government investment and public debt in an economic growth model. China Economic Review, 45, 257-278. doi:10.1016/j.chieco.2016.08.005

Cieślik, A., \&Goczek, Ł. (2018). Control of corruption, international investment, and economic growth Evidence from panel data. World Development, 103, 323-335. doi:10.1016/j.worlddev.2017.10.028

Checherita-Westphal, C., \& Rother, P. (2012). The impact of high government debt on economic growth and its channels: An empirical investigation for the euro area. European Economic Review, 56(7), 1392-1405. doi:10.1016/j.euroecorev.2012.06.007

Chen, S. S. (2014). Public Debt and Its Impacts on Output: A Long-Horizon Perspective. Available at SSRN: http://ssrn.com/abstract=2396292.

Chowdhury, A. R. (2001). External debt and growth in developing countries; a sensitivity and causal analysis(Discussion Paper No. 2001/95): WIDER

Claessens, S., \&Perotti, E. (2007). Finance and inequality: Channels and evidence. Journal of Comparative Economics, 35(4), 748-773. doi:10.1016/i.jce.2007.07.002

Cohen, D. (1993). Low investment and large lcd debt in the 1980's. The American Economic Review, 83, 437449.

De Haan, J., \& Sturm, J. (2017). Finance and income inequality: A review and new evidence. European Journal of Political Economy, 50, 171-195. doi:10.1016/j.ejpoleco.2017.04.007

Depken, C. A., \&Lafountain, C. L. (2006). Fiscal consequences of public corruption: Empirical evidence from state bond ratings. Public Choice, 126(1-2), 75-85. doi:10.1007/s11127-006-4315-0

De Mello, L. R. 1997. Foreign direct investment in developing countries and growth: A selective survey. Journal of Development Studies 34 (1): 1-34. doi:10.1080/00220389708422501.

Diamond, P. A. (1965). National debt in a neoclassical growth model. The American Economic Review, 55(5), 1126-1150.

Dollar, D., \&Kraay, A. (2004). Growth is Good for the Poor. Growth, Inequality, and Poverty, $29-61$. doi:10.1093/0199268657.003.0002

Donaubauer, J., Meyer, B. E., \&Nunnenkamp, P. (2015). A New Global Index of Infrastructure: Construction, Rankings and Applications. The World Economy, 39(2), 236-259. doi:10.1111/twec.12290 
Dutta, N., Kar, S., \&Saha, S. (2017). Human capital and FDI: How does corruption affect the relationship? Economic Analysis and Policy, 56, 126-134. doi:10.1016/j.eap.2017.08.007

Edgardo Campos, J., Lien, D., \& Pradhan, S. (1999). The Impact of Corruption on Investment: Predictability Matters. World Development, 27(6), 1059-1067. doi:10.1016/s0305-750x(99)00040-6

Elbadawi, I. A., Benno, J. N., \& Njuguna, N. U. (1999). Debt overhang and economic growth in Sub-Saharan Africa. Chapter 5. In Iqbal Zubair \& Ravi Kanbur (Eds.), External Finance for Low-Income Countries, pp. 49-76. Washington, DC: IMF Institute.

Enders, W. (2004). Applied Econometrics: Time Series. New Jersey: John Wiley \& Sons.

Friedman, E., Johnson, S., Kaufmann, D., \&Zoido-Lobaton, P. (2000). Dodging the grabbing hand: the determinants of unofficial activity in 69 countries. Journal of Public Economics, 76(3), 459-493. doi:10.1016/s0047-2727(99)00093-6

Greiner, A. (2012). Public debt in a basic endogenous growth model. Economic Modeling, 29(4), 1344-1348. doi:10.1016/j.econmod.2012.03.005

Greiner, A. (2012). Sustainable Public Debt and Economic Growth under Wage Rigidity. Metroeconomica, 64(2), 272-292.doi:10.1111/meca.12006

Gupta, S. (1998). Does Corruption Affect Income Inequality and Poverty? IMF Working Papers, 98(76), 1. doi:10.5089/9781451849844.001

Gyimah-Brempong, K. (2002). Corruption, economic growth, and income inequality in Africa. Economics of Governance, 3(3), 183-209. doi:10.1007/s101010200045

Gyimah-Brempong, K., \& De Gyimah-Brempong, S. M. (2006). Corruption, Growth, and Income Distribution: Are there Regional Differences? Economics of Governance, 7(3), 245-269. doi:10.1007/s10101-005-00082

Haris, R., \& Todaro, M. P. (1970). Migration, unemployment and development: A two sector analysis. American Economic Review, 126-142.

Haque, N. U., \&Nayab, D. (2006). Renew Cities to be the Engine of Growth. The Pakistan Development Review, 45(3), 505-509. doi:10.30541/v45i3pp.505-509

Hausman, J. A. (1978). Specification Tests in Econometrics. Econometrica, 46(6), 1251. doi:10.2307/1913827

Herzer, D. 2012. How does foreign direct investment really affect developing countries' growth?Review of International Economics 20 (2): 396-414. doi:10.1111/roie.2012.20.issue-2.

Hongdao, Q., Mumtaz, A., Mukhtar, H., Saleem, H. A., \& Azam, S. (2018). Corruption Prevention and Economic Growth: A Mediating Effect of Rule of Law. International Journal of Social Science Studies, 6(2), 128. doi:10.11114/ijsss.v6i2.2946

Johnson, A. 2006. The effects of FDI on host country economic growth. Working Paper 58. Stockholm, Sweden: Royal Institute of Technology, Centre of Excellence for Studies in Science and Innovation

Johnson, S., Kaufmann, D., Shleifer, A., Goldman, M. I., \& Weitzman, M. L. (1997). The Unofficial Economy in Transition. Brookings Papers on Economic Activity, 1997(2), 159. doi:10.2307/2534688

Justesen, M. K., \&Bjørnskov, C. (2014). Exploiting the Poor: Bureaucratic Corruption and Poverty in Africa. World Development, 58, 106-115. doi:10.1016/j.worlddev.2014.01.002

Karagol, E. (2002). The causality analysis of external debt service and GNP. The Case of Turkey”, Central Bank Review, 39-64.

Kaufmann, D., Kraay, A., \&Mastruzzi, M. (2013). The Worldwide Governance Indicators (WGI) project. World Bank.

Koenker, R., \& Bassett, G. (1978). Regression Quantiles. Econometrica, 46(1), 33. doi:10.2307/1913643

Krugman, P. (1988). Financing vs. forgiving a debt overhang. Journal of Development Economics, 29(3), 253268. doi:10.1016/0304-3878(88)90044-2

Kummer-Noormamode, S. (2014). Does Trade with China Have an Impact on African Countries' Growth? African Development Review, 26(2), 397-415. doi:10.1111/1467-8268.12100

Lambsdorff, J. G. (2003). How Corruption Affects Productivity. Kyklos, 56(4), 457-474. doi:10.1046/j.00235962.2003.00233.x

Lau, C. K., Yang, F. S., Zhang, Z., \& Leung, V. K. (2015). Determinants of Innovative Activities: Evidence from Europe and Central Asia Region. The Singapore Economic Review, 60(01), 1550004. doi:10.1142/s0217590815500046

Lundberg, L., \& Lyn, S. (1999). Inequality and Growth: Lessons for Policy. Washington, DC: WB. Mimeo

Lucas, R. E. (1988). On the mechanics of economic development. Journal of Monetary Economics, 22(1), 3-42. doi:10.1016/0304-3932(88)90168-7

Mankiw, N. G., Romer, D., \& Weil, D. N. (1992). A Contribution to the Empirics of Economic Growth. The Quarterly Journal of Economics, 107(2), 407-437. doi:10.2307/2118477

Mauro, P. (1998). Corruption and the composition of government expenditure. Journal of Public Economics, 69(2), 263-279. doi:10.1016/s0047-2727(98)00025-5 
Mencinger, J. 2003. Does foreign direct investment always enhance economic growth? Kyklos, International Review of Social Sciences 56 (4): 491-508

Mauro, P. (1995). Corruption and Growth. The Quarterly Journal of Economics, 110(3), 681-712. doi: $10.2307 / 2946696$

Milanovic, B., 1994. Determinants of cross-country income inequality: An “augmented” Kuznets' hypothesis. In: World Bank Policy Research Working Paper No 1246

Mo, P. (2001). Corruption and economic growth. Journal of Comparative Economics, 29, 66-79

Murray, M. P. (2006). Avoiding Invalid Instruments and Coping with Weak Instruments. Journal of Economic Perspectives, 20(4), 111-132. doi:10.1257/jep.20.4.111

Nguyen, T. Q., Clements, B. J., \& Bhattacharya, R. (2003). External Debt, Public Investment, and Growth in Low-Income Countries. IMF Working Papers, 03(249), 1. doi:10.5089/9781451875904.001

Olofsdotter, K. (1998). Foreign direct investment, country capabilities and economic growth. WeltwirtschaftlichesArchiv, 134(3), 534-547. doi:10.1007/bf02707929

Olken, B. A., \&Pande, R. (2012). Corruption in Developing Countries. Annual Review of Economics, 4(1), 479509. doi:10.1146/annurev-economics-080511-110917

Oyvat, C. (2016). Agrarian Structures, Urbanization, and Inequality. World Development, 83, 207-230. doi:10.1016/j.worlddev.2016.01.019

Page, J. (2006). Strategies for Pro-poor Growth: Pro-poor, Pro-growth or Both? Journal of African Economies, 15(4), 510-542. doi:10.1093/jae/ejk009

Petrou, A. P. (2014). Bank Foreign Affiliate Performance in the Face of Pervasive and Arbitrary Corruption. European Management Review, 11(3-4), 209-221. doi:10.1111/emre.12033

Poirson, H., Ricci, L. A., \& Pattillo, C. A. (2002). External Debt and Growth. IMF Working Papers, 02(69), 1. doi: $10.5089 / 9781451849073.001$

Poirson, H., Ricci, L. A., \& Pattillo, C. A. (2004). What Are the Channels Through Which External Debt Affects Growth? IMF Working Papers, 04(15), 1. doi:10.5089/9781451843293.001

Prechel, H. (1985). The Effects of Exports, Public Debt, and Development on Income Inequality. The Sociological Quarterly, 26(2), 213-234. doi:10.1111/j.1533-8525.1985.tb00225.x

Puente-Ajovín, M., \& Sanso-Navarro, M. (2015). Granger causality between debt and growth: Evidence from OECD countries. International Review of Economics \& Finance, 35, 66-77. doi:10.1016/j.iref.2014.09.007

Reisen, H., and Soto, M. 2001. Which types of capital inflows foster developing country growth?International Finance 4 (1): 1-14. doi:10.1111/infi.2001.4

Reinhart, C. M., \& Rogoff, K. S. (2010). Growth in a Time of Debt. American Economic Review, 100(2), 573578. doi:10.1257/aer.100.2.573

Saha, S., \& Ben Ali, M. S. (2017). Corruption and Economic Development: New Evidence from the Middle Eastern and North African Countries. Economic Analysis and Policy, 54, 83-95. doi:10.1016/j.eap.2017.02.001

Schneider, F., Buehn, A., \& Montenegro, C. (2010). Shadow economies all over the world: New estimates for 162 countries from 1999-2007, World Bank Policy Research Working Paper No. 5356

Sutherland, D., \&Hoeller, P. (2012). Debt and macroeconomic stability: An overview of the literature and some empirics., OECD Economics Department Working Papers, No. 1006, OECD Publishing.

Tanzi, V., \&Davoodi, H. (2002). Corruption, public investment, and growth. In G. T. Abed, \& S. Gupta (Eds.), Governance, corruption, and economic performance (pp. 280-299). Washington, DC: International Monetary Fund, Publication Services.

Tiongson, E., Davoodi, H. R., \&Asawanuchit, S. S. (2003). How Useful Are Benefit Incidence Analyses of Public Education and Health Spending. IMF Working Papers, 03(227), 1. doi:10.5089/9781451875430.001

Türkcan, B., Duman, A., and Yetkiner, I. H. 2008. How does FDI and economic growth affect each other? The OECD case. International Conference on Emerging Economic Issues in a Globalizing World, Izmir, Turkey, May 25. http://eco.ieu.edu.tr/wp-content/proceedings/2008/0802.pdf

Van Vu, H., Tran, T. Q., Van Nguyen, T., \& Lim, S. (2016). Types of Corruption and Firm Financial Performance: New Evidence from a Transitional Economy. Journal of Business Ethics, 148(4), 847-858. doi:10.1007/s10551-016-3016-y

Wei, S. (2000). How Taxing is Corruption on International Investors? Review of Economics and Statistics, 82(1), 1-11. doi:10.1162/003465300558533

Woo, J., \& Kumar, M. S. (2010). Public Debt and Growth. IMF Working Papers, 10(174), 1. doi: $10.5089 / 9781455201853.001$ 
Appendix

Table 7. Unit root results

\begin{tabular}{|c|c|c|c|c|c|c|c|c|}
\hline Variables & \multicolumn{2}{|c|}{ LLC } & \multicolumn{2}{|c|}{ IPS } & \multicolumn{2}{|l|}{$\mathrm{ADF}$} & \multicolumn{2}{|l|}{$\mathrm{PP}$} \\
\hline & Intercept & $\begin{array}{l}\text { trend\& } \\
\text { intercept }\end{array}$ & Intercept & $\begin{array}{l}\text { trend\& } \\
\text { intercept }\end{array}$ & Intercept & $\begin{array}{l}\text { trend\& } \\
\text { intercept }\end{array}$ & Intercept & $\begin{array}{l}\text { trend\& } \\
\text { intercept }\end{array}$ \\
\hline \multicolumn{9}{|l|}{ Level } \\
\hline GDP growth & $-10.08 * * *$ & $-11.52 * * *$ & $-9.96 * * *$ & $-8.06 * * *$ & $316.91 * * *$ & $274.11 * * *$ & $482.87 * * *$ & $413.73 * * *$ \\
\hline GINI & -0.10 & $-1.57^{*}$ & -0.20 & -0.528 & $122.48 * *$ & $115.57 * *$ & $132.67 * * *$ & $245.40 * * *$ \\
\hline Public debt & 58.45 & 5.23 & 26.55 & 3.83 & $125.9 * * *$ & $109.5^{* * *}$ & $110.30 * * *$ & $153.7 * * *$ \\
\hline $\begin{array}{l}\text { Kaufman } \\
\text { corruption }\end{array}$ & $-18.01 * * *$ & $-15.95 * * *$ & $-14.26^{* * *}$ & $-9.39 * * *$ & $562 * * *$ & $327.6^{* * *}$ & $2689.91 * * *$ & $2509.6^{* * *}$ \\
\hline TI corruption & $-6.55 * * *$ & $-6.60 * * *$ & $-4.70 * * *$ & $-6.30 * * *$ & $398.1 * * *$ & $386.5^{* * *}$ & $581.54 * * *$ & $746.4 * * *$ \\
\hline Shadow & $-80.23 * * *$ & $-10.30 * * *$ & $-56.37 * * *$ & $-23.21 * * *$ & $3525.3 * * *$ & $879.9 * * *$ & $11898.4 * * *$ & $11355.8^{* * *}$ \\
\hline Debt servicing & $-1.52 *$ & 1.57 & -1.13 & 0.59 & $91.7^{*}$ & 79.16 & $113.85^{* * *}$ & $96.70 *$ \\
\hline FDI & $-2.12 * *$ & $-2.09 * *$ & $-5.23 * * *$ & $-2.62 * * *$ & $215.1 * * *$ & $178.2 * * *$ & $358.51 * * *$ & $323.91 * * *$ \\
\hline GINFRA & $-9.31 * * *$ & $-7.91 * * *$ & $-6.18 * * *$ & $-5.03 * * *$ & $223.9 * * *$ & $203.4 * * *$ & $263.03 * * *$ & $211.36^{* * *}$ \\
\hline $\mathrm{HC}$ & $-3.34 * * *$ & 2.20 & 1.26773 & -0.83 & 136.63 & $196.7 * * *$ & $643.33 * * *$ & $493.3 * * *$ \\
\hline INF & $-72.82 * * *$ & $-148.30 * * *$ & $-30.41 * * *$ & $-33.37 * * *$ & $611.6^{* * *}$ & $533.8 * * *$ & $531.88 * * *$ & $440.9 * * *$ \\
\hline URBAN & $-11.26^{* * *}$ & 8.15 & 3.99 & $212.75^{* * *}$ & $384.22 * * *$ & $238.5^{* * *}$ & $917.8 * * *$ & $238.5^{* * *}$ \\
\hline GCF & $-4.10 * * *$ & $-1.72 * *$ & $-3.06^{* * *}$ & -0.030 & $171.28 * * *$ & 119.48 & $192.5^{* * *}$ & $137.2 *$ \\
\hline GDPPC & $-2.63 * * *$ & 2.54 & 2.98 & 4.50 & 125.33 & 92.57 & 128.04 & 109.47 \\
\hline GE & $-6.70 * * *$ & $-3.40 * * *$ & $-3.67 * * *$ & -0.31 & $182.09 * * *$ & 129.36 & $189.77 * * *$ & $162.41 * * *$ \\
\hline OPEN & $-5.42 * * *$ & $-4.47 * * *$ & $-3.14 * * *$ & $158.7 * * *$ & $158.8^{* * *}$ & $135.6^{* *}$ & $137.9 * *$ & $135.64 * *$ \\
\hline \multicolumn{9}{|l|}{ 1st difference } \\
\hline GDP growth & $-25.91 * * *$ & $-21.29 * * *$ & $-27.53 * * *$ & $-22.83 * * *$ & $855.47 * * *$ & $628.89 * * *$ & $4461.18 * * *$ & $3682.64 * * *$ \\
\hline GINI & $-19.10 * * *$ & $-18.54 * * *$ & $-19.90 * * *$ & $-17.23 * * *$ & $506.98 * * *$ & $413.77 * * *$ & $863.21 * * *$ & $859.87 * * *$ \\
\hline Public debt & $-2.03 * *$ & $-6.60 * * *$ & $-7.15^{* * *}$ & $-8.53 * * *$ & $232.52 * * *$ & $251.42 * * *$ & $259.65 * * *$ & $275.69 * * *$ \\
\hline $\begin{array}{l}\text { Kaufman } \\
\text { corruption }\end{array}$ & $-16.09 * * *$ & $-15.80 * * *$ & $-14.58 * * *$ & $-11.52 * * *$ & $317.12 * * *$ & $264.76^{* * *}$ & $1024.15^{* * *}$ & $646.082 * * *$ \\
\hline TI corruption & $-5.68 * * *$ & $-4.25 * * *$ & $-28.44 * * *$ & $-28.40 * * *$ & $1355.1 * * *$ & $625.95 * * *$ & $2075.7 * * *$ & $2643.7 * * *$ \\
\hline Shadow & $-14.96^{* * *}$ & $-15.36^{* * *}$ & $-13.03^{* * *}$ & $-4.15 * * *$ & $650.18 * * *$ & $253.83 * * *$ & $4807.91 * * *$ & $4179.61^{* * *}$ \\
\hline Debt servicing & $-8.50 * * *$ & $-6.37 * * *$ & $-11.65^{* * *}$ & $-8.46 * * *$ & $279.24 * * *$ & $204.88 * * *$ & $874.31 * * *$ & $828.06^{* * *}$ \\
\hline FDI & $-13.03 * * *$ & $-8.10 * * *$ & $-17.79 * * *$ & $-12.84 * * *$ & $546.71 * * *$ & $389.20 * * *$ & $1890.64 * * *$ & $1683 * * *$ \\
\hline GINFRA & $-21.86^{* * *}$ & $-18.28 * * *$ & $-21.90 * * *$ & $-18.81 * * *$ & $655.73 * * *$ & $525.81 * * *$ & $1421.16^{* * *}$ & $1422.4^{* * *}$ \\
\hline $\mathrm{HC}$ & -0.55 & $-77.8 * * *$ & $-10.11^{* * *}$ & $-35.10 * * *$ & $461.61 * * *$ & $246.38 * * *$ & $899.53 * * *$ & $603.95 * * *$ \\
\hline INF & $-119.9 * * *$ & $-94.17 * * *$ & $-40.24 * * *$ & $-34.06 * * *$ & $1013.96^{* * *}$ & $592.46 * * *$ & $2788.92 * * *$ & $2589.93 * * *$ \\
\hline URBAN & $-6.9 * * *$ & 1.07 & $-9.66^{* * *}$ & $221.78 * * *$ & $451.49 * * *$ & $201.30 * * *$ & $336.03 * * *$ & $201.3 * * *$ \\
\hline GCF & $-23.88^{* * *}$ & $-20.89 * * *$ & $-21.92 * * *$ & $-17.745^{* * *}$ & $634.17 * * *$ & $476.64 * * *$ & $755.15^{* * *}$ & $630.94 * * *$ \\
\hline GDPPC & $-19.52 * * *$ & $-19.46^{* * *}$ & $-18.56^{* * *}$ & $-16.26^{* * *}$ & $550.60 * * *$ & $455.72 * * *$ & $1071.2 * * *$ & $1029.36^{* * *}$ \\
\hline GE & $-25.83 * * *$ & $-23.8 * * *$ & $-23.45^{* * *}$ & $-19.91 * * *$ & $683.18 * * *$ & $534.18 * * *$ & $1007.27 * * *$ & $956.60 * * *$ \\
\hline OPEN & $-14.3 * * *$ & $-7.11 * * *$ & $-13.56^{* * *}$ & $328.98 * * *$ & $389.08 * * *$ & $583.96 * * *$ & $684.48 * * *$ & $583.9 * * *$ \\
\hline
\end{tabular}

Note: $*, * *$, and $* * *$ represents significance at $10 \%, 5 \%$ and $1 \%$ respectively. 
Table 8 . List of BRI countries

\begin{tabular}{|c|l|c|l|c|l|}
\hline S. No & Country & S. No & Country & S. No & Country \\
\hline 1 & Albania & 21 & Jordan & 41 & Qatar \\
\hline 2 & Armenia & 22 & Kazakhstan & 42 & Romania \\
\hline 3 & Austria & 23 & Kuwait & 43 & Russian Federation \\
\hline 4 & Azerbaijan & 24 & Latvia & 44 & Saudi Arabia \\
\hline 5 & Bahrain & 25 & Lebanon & 45 & Senegal \\
\hline 6 & Bangladesh & 26 & Libya & 46 & Serbia \\
\hline 7 & Belarus & 27 & Lithuania & 47 & Singapore \\
\hline 8 & Bolivia & 28 & Madagascar & 48 & Slovak Republic \\
\hline 9 & Bulgaria & 29 & Malaysia & 49 & Slovenia \\
\hline 10 & China & 30 & Moldova & 50 & South Africa \\
\hline 11 & Croatia & 31 & Mongolia & 51 & Sri Lanka \\
\hline 12 & Czech Republic & 32 & Morocco & 52 & Syrian Arab \\
\hline 13 & Egypt, Arab Rep. & 33 & Myanmar & 53 & Thailand \\
\hline 14 & Estonia & 34 & New Zealand & 54 & Trinidad and Tobago \\
\hline 15 & Ethiopia & 35 & Oman & 55 & Tunisia \\
\hline 16 & Hungary & 36 & Pakistan & 56 & Turkey \\
\hline 17 & India & 37 & Panama & 57 & Ukraine \\
\hline 18 & Iran, Islamic Rep. & 38 & Papua New Guinea & 58 & United Arab \\
\hline 19 & Iraq & 39 & Philippines & 59 & Vietnam \\
\hline 20 & Israel & 40 & Poland & 60 & Yemen, Rep. \\
\hline
\end{tabular}

